\title{
Knowledge of Farmers towards Reasons for Decline of Orange Orchards in Amravati District, India
}

\author{
Krishn Kumar Verma ${ }^{1}$, Anita Deshmukh ${ }^{2}$ and Kamlesh Ahirwar ${ }^{3 *}$ \\ ${ }^{1}$ College of Agriculture Rewa (M.P.), India \\ ${ }^{2}$ (ATARI) JNKVV Jabalpur (M.P.), India \\ ${ }^{3}$ Krishi Vigyan Kendra Chhatarpur (M.P.), India \\ *Corresponding author
}

\section{A B S T R A C T}

The present investigation entitled "knowledge of farmers towards reasons for decline of orange orchards in Amravati District" has planned and conducted with the general objectives to study the knowledge of orange growers and exploratory design of social research was used in the

Keywords

Frequency, Mean, Standard deviation,

Correlation and multiple regression

Article Info

Accepted:

16 April 2018

Available Online:

10 May 2018 present study. In all, 150 farmers were selected by personally interviewing the respondents with the help of structural schedule. Collected data were carefully examined, classified and tabulated. Frequency, mean, standard deviation, correlation and multiple regression analysis have been summarized as below. Findings reveled that majority of the respondents were of young and old age group and most of the respondents were educated upto high school level. Near about half of the respondents were in medium land holding range between 4.01 to 10 hectares. Whereas, majority of the respondents had high family size. Nearly $88 \%$ of the respondents had medium size of orchard. Most of them had their annual income ranging from Rs. 1, 00,001 to Rs. 1, 50,000/- and were belonged to lower middle category of socio-economic status. However most of the respondents had low source of information and most of the respondents had well as the sources of irrigation and most of the respondents had high experience in orange cultivation. Findings revealed that majority of the respondents possessed medium level of knowledge about the recommended orange cultivation practices. The per cent change in area under orange was 80.67 per cent.

\section{Introduction}

Nagpur Mandarin orange is one of the most important fruits of Maharashtra state. The area production and yield per hectare of orange in Maharashtra during the year 2012-13 were 311.00 hectares (000), 2524 tones (000) and $9898.00 \mathrm{Kg} / \mathrm{ha}$ respectively. The important orange growing districts in Maharashtra are Nagpur, Amravati, Wardha, Yavatmal and Akola. In Amravati District orange cultivation covers an area of 48081.50 hectares with production of $336570.75 \mathrm{MT}$ and productivity of 6.27 MT/ha during 2013-14. This shows that the average yield of orange in Amravati district is 8.0512 tones/ ha. Which is obviously 13ess that average yield of Maharashtra state (9.731 tones/ha) In spite of the high genetic potential in the crop and availability of latest technology the productivity of orange remained at 8.0512 tones/ha probably, it may be because of 
various production constraints like non availability of inputs and their exorbitant prices (Chikhale, 1993 and Bhople et al., 1996) lack of knowledge and skill (Gomase, 1997) and irrigation constraints (Kadam, 1999). In this context the present study was undertaken to identify the constraints encountered by orange growers during use of various reasons for decline of orange cultivation.

\section{Materials and Methods}

The study was conducted in purposively selected Achalpur Panchayat Samiti of Amravati district in Maharashtra state. The list of villages having cultivation of orange was obtained from the office of the panchayat samiti Achalpur. Out of these, 15 villages were purposively selected on the basis of large area under orange. A list of orange growers with orange orchards in bearing stage was prepared from each selected village in consultation with Gramsevak and Talathi of respective villages. From this list, 150 orange growers were selected for the study. The data were gathered through personal interview with the selected orange growers with the help of an interview schedules in the orange orchards. The independent variables were selected age, education, family size, landholding, annual income, size of orchard, socio economic status, innovativeness, risk preference etc. The statistical tools namely mean, standard deviation, co-efficient, of correlation and coefficient of regression were adapted to test the significantly of the results.

\section{Results and Discussion}

Distribution of the respondents according to their practice wise knowledgethe knowledge of orange growers as per planning was studied and data depicted in Table 1 clearly shows that that respondents had knowledge about recommended percent of hormone for control of fruit dropping (48 per cent), Major disease of orange (78 per cent), Pest control measure (81.33 per cent), Training seasons (81.33 per cent), Lime concentration (82 per cent), Disease control measure (82.67 per cent), Pit depth (84.00 per cent), Recommended training method (84.00 per cent), Fertilizers recommendation (84.67 per cent), Major pest of orange crop (84.67 per cent), Pit filling material (84.67 per cent), Interval for irrigation orchards (85.33 per cent), Recommended hormone use for fruit dropping (85.33 per cent), Selection of root stock(85.33per cent), Soil type85.33 per cent, Plantation method (86.67 per cent), Economical year (87.33 per cent), Intercrops (87.33 per cent), recommended numbers of irrigation (87.33 per cent), Planting space (88.00 per cent), Recommended does for application of Bourdeux mixture (88.00 per cent), Recommended does for application of Bourdeux mixture $(88.00$ per cent), Recommended no. of fruit per plant (88.67 per cent), Variety (88.67 per cent), Applying Bourdeux mixture to trunk from ground level (89.33 per cent), Propagation method 89.33 per cent, Plants/ha (90.67per cent), Recommended bahar treatment/year (90.67 per cent), Recommended period for cultivation of intercrops 90.67 per cent, Method of irrigation (91.33 per cent), Planting seasons (91.33 per cent), Pruning method91.33 per cent, Recommended month for Bourdeux mixture (91.33 per cent), Recommended period for stopping irrigation prior to harvesting of fruit (91.33 per cent), Recommended time for water stress 92.00 per cent, Pruning season (92.67 per cent), Flowering time of mrug bahar (94.00 per cent), Recommended tillage operation at the time of fruiting stage (94.67per cent), Flowering time ambia bahar (95.33 per cent), Harvesting time of ambia bahar (96.00 per cent), Harvesting time of mrug bahar (96.67 per cent), Intercropping system (96.67 per cent). 
Table.1 Distribution of the respondents according to their practice wise knowledge

\begin{tabular}{|c|c|c|c|}
\hline \multirow{2}{*}{$\begin{array}{l}\text { Sr. } \\
\text { No } \\
\end{array}$} & \multirow[t]{2}{*}{ Practices } & \multicolumn{2}{|c|}{ Knowledge (N=150) } \\
\hline & & Frequency & Percentage \\
\hline 1 & Soil type (medium black) & 128 & 85.33 \\
\hline 2 & Pit depth $(\mathbf{1 x 1 x 1 m )}$ & 126 & 84.00 \\
\hline 3 & Lime concentration (7 $\mathbf{p H})$ & 123 & 82.00 \\
\hline 4 & Planting seasons (monsoon) & 137 & 91.33 \\
\hline 5 & Propagation method (grafting) & 134 & 89.33 \\
\hline 6 & Selection of root stock (Jamberi and Rangpur) & 128 & 85.33 \\
\hline 7 & Plantation method (square) & 130 & 86.67 \\
\hline 8 & Planting space $(\mathbf{6 x 6 m})$ & 132 & 88.00 \\
\hline 9 & Plants/ha (277) & 136 & 90.67 \\
\hline 10 & Size of pits $(\mathbf{1} \times 1.5 \mathrm{~m})$ & 132 & 88.00 \\
\hline 11 & Pit filling material (FYM 5kg + SSP 1/2kg/pit) & 127 & 84.67 \\
\hline 12 & Variety (Kinnow, Nagpuri) & 133 & 88.67 \\
\hline 13 & Fertilizers recommendation $(1: 1.25: 1)$ & 127 & 84.67 \\
\hline 14 & Recommended numbers of irrigation (22) & 131 & 87.33 \\
\hline 15 & Method of irrigation (Furrow) & 137 & 91.33 \\
\hline 16 & $\begin{array}{l}\text { Intercropping system (Kharif- green gram, black gram, and soybean. } \\
\text { Rabi- gram, wheat, tur) }\end{array}$ & 145 & 96.67 \\
\hline 17 & Intercrops (vegetables viz., spinach, onion) & 131 & 87.33 \\
\hline 18 & Recommended period for cultivation of intercrops ( $2-3$ years $)$ & 136 & 90.67 \\
\hline 19 & Recommended training method (cutting) & 126 & 84.00 \\
\hline 20 & Training seasons (June) & 122 & 81.33 \\
\hline 21 & Pruning method (cutting) & 137 & 91.33 \\
\hline 22 & Pruning season (June-oct) & 139 & 92.67 \\
\hline 23 & Recommended bahar treatment/year (Ambia, mrug) & 136 & 90.67 \\
\hline 24 & Recommended time for water stress (before harvesting) & 138 & 92.00 \\
\hline 25 & Interval for irrigation orchards (50 days) & 128 & 85.33 \\
\hline 26 & Recommended does for application of Bourdeux mixture (1:1:10) & 132 & 88.00 \\
\hline 27 & Recommended month for Bourdeux mixyure (June- oct) & 137 & 91.33 \\
\hline 28 & Applying Bourdeux mixture to trunk from ground level (1 to $\mathbf{1 . 5 m})$ & 134 & 89.33 \\
\hline 29 & Recommended tillage operation at the time of fruiting stage (harrowing) & 142 & 94.67 \\
\hline 30 & Recommended hormone use for fruit dropping (NAA) & 128 & 85.33 \\
\hline 31 & $\begin{array}{l}\text { Recommended percent of hormone for control of fruit dropping (NAA } \\
\mathbf{1 0 p p m}+\mathbf{1} \text { per cent urea }+ \text { per liter water) }\end{array}$ & 72 & 48.00 \\
\hline 32 & Recommended no. of fruit per plant $(\mathbf{5 0 0 - 7 0 0 )}$ & 133 & 88.67 \\
\hline 33 & $\begin{array}{l}\text { Recommended period for stopping irrigation prior to harvesting of fruit } \\
\text { (50days) }\end{array}$ & 137 & 91.33 \\
\hline 34 & Economical year(18 -25 years) & 131 & 87.33 \\
\hline 35 & Major disease of orange (citrus canker, gummosis of citrus) & 117 & 78.00 \\
\hline 36 & Disease control measure (Bordux mixture, ridomi $7 \mathbf{M z}$ ) & 124 & 82.67 \\
\hline 37 & Major pest of orange crop (citrus black hopper, citrus white fly) & 127 & 84.67 \\
\hline 38 & Pest control measure (Monocrotophos) & 122 & 81.33 \\
\hline 39 & Flowering time of mrug bahar (June-July) & 141 & 94.00 \\
\hline 40 & Flowering time ambia bahar(Jan-Feb) & 143 & 95.33 \\
\hline 41 & Harvesting time of mrug bahar (Feb-march) & 145 & 96.67 \\
\hline 42 & Harvesting time of ambia bahar (Nov-Dec) & 144 & 96.00 \\
\hline
\end{tabular}


Table.2 Distribution of respondents on the extent of their knowledge level

\begin{tabular}{|c|c|c|c|}
\hline \multirow[t]{2}{*}{ Sr.no. } & \multirow[t]{2}{*}{ Category } & \multicolumn{2}{|c|}{ Respondents $n=150$} \\
\hline & & Frequency & Percentage \\
\hline 1 & Low & 15 & 10.00 \\
\hline 2 & Medium & 121 & 80.67 \\
\hline 3 & High & 14 & 9.33 \\
\hline & Total & 150 & 100 \\
\hline
\end{tabular}

Thus, it can be concluded that the majority of the respondents had knowledge about maturity signs, soil type, average yield, protective irrigation, number of spraying and dusting, land preparation operation, preparatory village and intercropping system.

Beside investigation of practice wise knowledge the researcher has also made an attempt to categorize the respondents on the basis of extent of knowledge they possessed in respect of orange cultivation.

Distribution of the respondents according to their knowledge distribution of the respondents according to their knowledge level (Table 2) revealed that most of the respondents (80.67 per cent) had medium knowledge about recommended orange cultivation practices, followed by 10.00 per cent of the respondents with low knowledge. However only 9.33 per cent of the respondents belong to the category of high level knowledge.

The orange growers were low knowledge about all practices as per plan prepared by them earlier. The important reasons reported by orange growers in use of various resources in accordance of plan were exorbitant prices and non-availability fertilizers ignorance and lack of knowledge of soil testing, use of growth regulators and pests and disease and their control measures, non-availability of labour and irregular electric supply. In order to promote the efficient management and use of various reasons required for the decline of orange orchards. It is essential to the orange growers with requisite and judicious use of man, material and capital resources.

\section{References}

Ahire, R.D., R.R. Kulkarni and A.H. Lunabat, (1999). Correlates of Knowledge grape technology. Maha. J. Extn. Educ. XVIII: 193-194

Bhople, P.P., P.S. Shinde and S.R. Bhople (1998): Pattern of information management by orange grower. Maha j. Exten. Educ. 15: 57-61.

Bhople, R.S., P.S. Shinde and V.R. Nimje (1996). Production and marketing constraints faced by orange growers. Maha. j. Ext. Educ. 15: 57-61.

Borkar, M.M., G.G. Chote and A.D. Lanjewar (2000): Characteristics of farmers influencing their knowledge about use of biofertilizers. Maha. J. Ext. Educ. 19: 130-131.

Chikhale, N.J. (1993). Constraints in adoption of recommended orange cultivation practices. M.Sc. (Agri) thesis (Unpub.), Dr. PDKV, Akola.

Gomase, A.S. (1997). Adoption behaviour of Kagzi lime (Citrus aurantifoliai Swingle) growers. M.Sc. (Agri) thesis (Unpub.), Dr. PDKV, Akola.

Jadhav, R.M. (2006): Knowledge and adoption of orange rootstock by orange growers. M.Sc. Thesis (Unpub.) Dr. PDKV, Akola.

Jagdale V., S.D. Nimbalkar (1993): Role of socio-personal economic and 
psychological characteristics of farmers on knowledge level about the improves dry land technology. Maha. J. Exten. Educ. 12. 119-124.
Kadam, A.L. (1999) Constraints in management of orange orchards faced by frmers. M.Sc. (Agri) thesis (Unpub.), Dr. PDKV, Akola.

\section{How to cite this article:}

Krishn Kumar Verma, Anita Deshmukh and Kamlesh Ahirwar. 2018. Knowledge of Farmers towards Reasons for Decline of Orange Orchards in Amravati District, India. Int.J.Curr.Microbiol.App.Sci. 7(05): 2009-2013. doi: https://doi.org/10.20546/ijcmas.2018.705.236 